Teknomekanik

Vol.1, No.1, June 2018, pp. 12 17

E-ISSN: 2621 - $8720 \quad$ P-ISSN: 2621 - 9980

\title{
Differences Strength of Low Carbon Stainless Steel St 37 with Electrical Welding Compound V Use Materials Add Electrodeof Type-RB and Type -RD
}

\author{
Refdinal, Ramli and Rio Andesko \\ Jurusan Teknik Mesin, Fakultas Teknik, Universitas Negeri Padang, Indonesia
}

\begin{tabular}{l}
\hline \hline Article Info \\
\hline Article history: \\
Received Jan $24^{\text {th }}, 2018$ \\
Revised March $11^{\text {th }}, 2018$ \\
Accepted May $24^{\text {th }}, 2018$ \\
\hline
\end{tabular}

\section{Keywords:}

Electrode Type

Low Carbon Steel

Welding

Hem

Tensile Test

\begin{abstract}
This study aims to determine the difference in tensile strength of low carbon steel St 37 which is welded with RB type and RD type electrodes. The welding utilizes the type of a V-shaped joint with an angle of 600. After low carbon steel St 37 is then subjected to a tensile strength test / tensile test to obtain a tensile strength value. This research uses experimental method by preparing the object of research in the form of tensile test specimen which amounted to 19 pieces and separated into 3 groups. Group I was an untreated / non-welded St 37 carbon steel, a Group II of low carbon steel St 37 welded with RB type electrodes, and a Group III of low carbon steel St 37 welded with RD type electrodes. The cooling medium used after welding is air. The tensile test results show that the average tensile strength of low carbon steel St 37 without welding has a tensile strength of $48.02 \mathrm{~kg} / \mathrm{mm}^{2}$ with the largest specimen tensile strength of $48.33 \mathrm{~kg} / \mathrm{mm}^{2}$ and strength At the low carbon steel welding St 37 using RB type electrode has an average tensile strength of $29.86 \mathrm{~kg} / \mathrm{mm}^{2}$ with the tensile strength of the largest specimen of $34.51 \mathrm{~kg} / \mathrm{mm}^{2}$ and the tensile strength of the lowest specimen is $25.00 \mathrm{~kg} / \mathrm{mm}^{2}$. While on the low carbon steel welding St 37 using RD type electrode has an average power of $31.83 \mathrm{~kg} / \mathrm{mm}^{2}$ with the tensile strength of the largest specimen is $34.51 \mathrm{~kg} / \mathrm{mm}^{2}$ and the tensile strength of the lowest specimen is $25.81 \mathrm{~kg} / \mathrm{mm}^{2}$. Based on the analysis and T test of low carbon steel welding ST 37 using RB type electrode and RD type there is no significant tensile strength difference.
\end{abstract}

\section{Corresponding Author:}

Refdinal,

Jurusan Teknik Mesin, Fakultas Teknik, Universitas Negeri Padang

Jln. Prof. Dr. Hamka Air Tawar, Padang (25131), Sumatera Barat, Indonesia

Email: ref_moein@yahoo.com

\section{INTRODUCTION}

The use of carbon steel is widely found in the community. To maximize its use need further treatment one of the most widely done is by welding. The most widely used carbon steel in welding is low carbon steel. Low carbon steel is widely used because the steel has a good durability and has an affordable price. ST 37 steel is one of low carbon steel having carbon content of $0.13-0.18 \%$. ST 37 is the standard naming of steel according to DIN (Deutsche Industrie Norman). The meaning of ST itself is an abbreviation of Steel while the number 37 means showing a limit for tensile strengths between $37 \mathrm{~kg} / \mathrm{mm}^{2}-49 \mathrm{~kg} / \mathrm{mm}^{2}$. Welding is the process of connecting two metals using heat energy and is widely used in manufacturing, reparation and metal engineering processes in the industrial world [1]. Welding results are influenced by several factors such as the state of equipment, control, and skill of a welder. The control includes the type of camp, the use of electrodes, Position of welding, flow selection and others. Good welding results are a requirement but a welder often does not pay attention to the controlling factor electrode selection must match the type of work and current to be used. Electrode selection by a welder is largely customary without knowing in detail what type of electrode is appropriate [2]. There are different brands of electrodes and different types that we find in the market. Among them are RB brand Kobe Steel, RD brand type Nikko Steel and others. With different brands of course have standard specifications, excellence, welding results and purchase price is different what else seen from the change in mechanical properties in the metal welding [3]. The author will conduct research and testing one of the mechanical properties of the material that is tensile strength on low carbon steel ST 37 after welding. The study used a low carbon steel plate (ST 37) using a single welded V-welding

Journal homepage: http://teknomekanik.ppj.unp.ac.id

DOI: https://doi.org/10.24036/tm.v1i1.472 
electrode using a Kobe Steel RB $26 \emptyset 3.2 \mathrm{~mm}$ and Nikko Steel RD $460 \emptyset 3.2 \mathrm{~mm}$ Nikko Steel RD type. After that the test is done tensile test and data to be analyzed only tensile stress.

\section{WELDING}

Based on the definition of DIN welding is a metallurgical bond on metal or metal alloy joints that are carried out in a melted or liquid state. Meanwhile, according to British Standards Institution (BS) Welding is the process of grafting between two or more materials in plastic or liquid state by using heat or by pressure or both. The filler metal with the melting temperature equal to the melting point of the parent metal may or may not be used in the grafting process. From this definition it can be further elucidated that the weld is the local connection of several metal rods using heat energy [4]. Electrical welding is the joining of two or more metals into one by melting or liquefaction with an electric arc. So electric welding or electric arc welding is a process of grafting metal by utilizing electric power as a source of heat. The heat generated by an electric arc occurs between the welding electrode and the workpiece. Electrodes melt together with workpieces resulting from an electric arc [5]. Wrapped electrode welding is a widely used welding method for metal welding. Welding using metal wire electrodes wrapped with flux. The type of electrode used determines the welding results so it is important to know the nature and type of each electrode as the basis for selecting the right electrode. Soft steel and low alloy steel electrodes for arc welding according to AWS classification (American Welding Society) are expressed with the E XXXX sign which means as follows:

$\mathrm{E}=$ Declares an electric arc electrode.

$\mathrm{XX}=$ (second and third number) after $\mathrm{E}$ represents the tensile strength of the weld deposit in thousands of $\mathrm{lb} / \mathrm{in}^{2}$.

$\mathrm{X}=$ (third number) states the position of welding. Number 1 for welding of all positions. Number 2 for flat position welding under the hand.

$\mathrm{X}=$ (fourth number) states the type of membrane and the type of current suitable for welding (Daryanto, 2012:61).

For example, $\mathrm{E} 6013$ means:

$\mathrm{E}=$ Welding electrode.

$60=$ The minimum tensile strength of the weld deposit is $60.000 \mathrm{lb} / \mathrm{in}^{2}$ or $42 \mathrm{~kg} / \mathrm{mm}^{2}$.

$1=$ Can be used for welding all positions.

3 = Type of Rutil-Kalium electrode membrane and welding with AC or DC current.

\section{Electrode RB-26 AWS A5.1 E 6013}

Electrode RB-26 has ASME / AWS A5.1 JIZ 3211 E 6013 is welded welding type for low carbon steel welding, this type of welding wire is widely used for plate welding, iron, pipe and others. R in RB stands for Rutil which is the main ingredient in flux coating. While B to constitute a closed protective slag electrode. Current used between 60 - 125 A. Have chemical composition: $0.08 \%$ C, 0,30 \% Si, 0,37\% Mn, 0,012 \% P, $0,010 \% \mathrm{~S}$.

\section{Electrode RD-460 AWS A5.1 E 6013}

Electrode RD-460 has ASME / AWS A5.1 JIZ 3211 E 6013 specification is a type of welding wire which is widely used for welding of many carbon steel, red and medium, plate, iron and pipe. R in RD stands for Rutil which is the material in flux coating. Whereas $\mathrm{D}$ is a carbon steel electrode. Current used between 80 - 140 A. Have chemical composition: 0,09\% C, $0,35 \%$ Si, 0,5\% Mn, 0,02 \% P, 0,02 \% S, 0,06\% Cr, 0,04 Ni, 001\% Mo (Nikko Welding Handbook, 2013: 8).

\section{Hem V}

Welding is the shape of the joint and is also part of the parent metal which will be filled by welding metal, the welding weld initially is a welding link which is then filled with weld metal. Before welding, it is necessary to prepare the parts to be welded to obtain a good and strong connection. The weld form of the weld is adjusted to the thickness of the workpiece, the welding position, the welded material and the desired strength. V Camp is used to connect metal / plate with 600-800 angle of swell and gap of about $2 \mathrm{~mm}$ and base height up to $1-2 \mathrm{~mm}$ and can be welded with plate thickness of about $4 \mathrm{~mm}-20 \mathrm{~mm}$ (Hery Sonawan, 2003: 29). At welding time $\mathrm{V}$ may be provided with a fluid retaining plate throughout the camp which is useful for preventing diluted bottom fluid and the retaining plate may be opened when needed. 


\section{Low Carbon Steel}

Carbon steel is an alloy of iron with carbon with a carbon content of less than $0.3 \%-1.7 \%$ in addition to it also contains other alloying elements. ST 37 steel is one of low carbon steel because it has carbon content $0,13-0,18 \%$, silicon $0,09 \%$ mangan $0,30 \%$, posfor $0,30 \%$ and sis is contain iron element. ST 37 is the standard naming of steel according to DIN. The meaning of ST itself is an abbreviation of Steel (steel) while the number 37 means showing the minimum tensile strength $\geq 37 \mathrm{~kg} / \mathrm{mm}^{2}$. Maximum tensile strength limit possessed can reach as big as $48 \mathrm{~kg} / \mathrm{mm}^{2}$ (DIN 17100).

\section{Metallurgy Las}

Generally, the microstructure of steel depends on its cooling speed from the temperature of the austenite to the room temperature. Because of these structural changes, the mechanical properties are also changed. This change occurs in several different regions of the welding as follows:

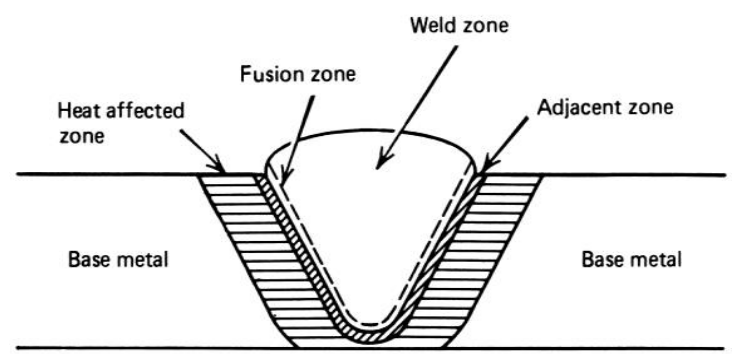

Figure 1 : Welding Area

a. Las Metal Region

This weld metal area is where the metal area is melted and then freezes at the time of welding.

b. HAZ (Heat Affected Zone)

In this area of heat influence is the base metal area adjacent to the weld metal area.

c. Metal Parent

This parent metal is the base of the metal that does not undergo any structural changes during which the heating process occurs.

\section{Tensile Testing}

Tensile testing is done to complement the basic design information of the strength of a material and as a supporting data for the material specification. Because with tensile testing can be measured resistance of a material to the static force given slowly. This tensile test is one of the most important tests to do, because with this test it can provide various information about metallic properties.

Tensile test analysis includes three things, namely:

1. Analyze diagram of tensile test results,

2. Analysis of test objects that have been broken,

3. Analysis of objects during withdrawal.

The test is performed to determine the mechanical properties of a material, especially the metal among the mechanical properties which can be known from the tensile test results are as follows: Tensile strength, Strong yield, Tenacity, Modulus of elasticity, Toughness, Interests.

$$
\begin{aligned}
& \text { Tensile strength }=\frac{\text { greatest style }}{\text { initial cross-sectional area }} \text { or } \\
& \sigma=\frac{F}{A o}
\end{aligned}
$$

Where :

$$
\begin{aligned}
& \sigma=\text { The internal stress } \mathrm{kg} / \mathrm{mm}^{2} \\
& \mathrm{~F}=\text { Style in } \mathrm{kg} \\
& \text { Ao= Initial cross-sectional area }\left(\mathrm{mm}^{2}\right)
\end{aligned}
$$

\section{METHOD}

This study was an experimental study comparing two different types of elektoda used in the low carbon steel welding ST 37 which was connected with electric welding using the connection of V. The cooling 
medium used was air, then tensile testing was performed. This research was conducted in Workshop of Mechanical Engineering, Department of Mechanical Engineering, Faculty of Engineering, State University of Padang.

\section{RESULTS}

Table 1. Results of Tensile Testing

\begin{tabular}{|c|c|c|c|c|c|c|c|c|}
\hline No & Test Group & Specimen & $\begin{array}{c}\mathrm{w} \\
(\mathrm{mm})\end{array}$ & $\begin{array}{c}\mathrm{t} \\
(\mathrm{mm})\end{array}$ & $\begin{array}{l}\text { Style } \\
\text { End } \\
(\mathrm{kg})\end{array}$ & $\begin{array}{c}\text { Biggest } \\
\text { Style } \\
(\mathrm{kg})\end{array}$ & $\begin{array}{c}\sigma \max \\
\left(\mathrm{kg} \cdot \mathrm{mm}^{2}\right)\end{array}$ & $\begin{array}{c}\sigma_{\mathrm{pts}} \\
\left(\mathrm{kg} / \mathrm{mm}^{2}\right)\end{array}$ \\
\hline \multirow{5}{*}{1} & \multirow{5}{*}{$\begin{array}{l}\text { Group I } \\
\text { (without } \\
\text { welding) }\end{array}$} & 1 & 13,2 & 6 & 3703,84 & 3828,31 & 48,33 & 46,47 \\
\hline & & 2 & 12,9 & 6 & 3120,33 & 3703,92 & 47,85 & 40,13 \\
\hline & & 3 & 13 & 6 & 2229,72 & 3762,14 & 48,23 & 28,58 \\
\hline & & 4 & 13 & 6 & 2883,19 & 3741,15 & 47,96 & 36,96 \\
\hline & & 5 & 12,9 & 6 & 2869,18 & 3702,12 & 47,83 & 37,06 \\
\hline \multirow{7}{*}{2} & \multirow{7}{*}{$\begin{array}{l}\text { Group II } \\
\text { (RB } \\
\text { Electrodes) }\end{array}$} & 1 & 13 & 6 & 1976,54 & 2691,64 & 34,51 & 25,34 \\
\hline & & 2 & 12,9 & 6 & 1758,82 & 2529,7 & 32,68 & 22,72 \\
\hline & & 3 & 13 & 6 & 1809,07 & 2587,22 & 33,17 & 23,19 \\
\hline & & 4 & 12,9 & 6 & 1809,07 & 2377,5 & 30,71 & 25,81 \\
\hline & & 5 & 13 & 6 & 2013,26 & 2151,94 & 27,58 & 25,81 \\
\hline & & 6 & 13 & 6 & 1814,11 & 1950,38 & 25,01 & 23,25 \\
\hline & & 7 & 13 & 6 & 1821,76 & 1979,84 & 25,38 & 23,19 \\
\hline \multirow{7}{*}{3} & \multirow{7}{*}{$\begin{array}{l}\text { Group II } \\
\text { (Electrode } \\
\text { RD) }\end{array}$} & 1 & 13 & 6 & 1809,07 & 2556,66 & 32,77 & 23,19 \\
\hline & & 2 & 13 & 6 & 2427,44 & 2433,36 & 31,19 & 23,56 \\
\hline & & 3 & 12,9 & 6 & 1625,23 & 2287,65 & 29,56 & 20,99 \\
\hline & & 4 & 13 & 6 & 1625,23 & 2447,03 & 31,37 & 20,83 \\
\hline & & 5 & 12,9 & 6 & 1976,54 & 2691,64 & 34,78 & 25,53 \\
\hline & & 6 & 13 & 6 & 1580,28 & 2834,87 & 25,81 & 20,86 \\
\hline & & 7 & 13 & 6 & 2470,26 & 2789,34 & 37,35 & 31,67 \\
\hline
\end{tabular}

Table 2. Average Strength Result Data

\begin{tabular}{ccccccccc}
\hline \multirow{2}{*}{ Test Group } & \multicolumn{8}{c}{ Tensile strength $(\sigma)$ Specimen $\left(\mathrm{kg} / \mathrm{mm}^{2}\right)$} \\
\\
& 1 & 2 & 3 & 4 & 5 & 6 & 7 & \multirow{2}{*}{ Average } \\
\hline Without Las & 48,33 & 47,85 & 48,23 & 47,96 & 47,83 & & & 48,04 \\
Electrode RB & 34,51 & 32,68 & 33,16 & 30,71 & 27,58 & 25 & 25,38 & 29,86 \\
Electrode RD & 32,77 & 31,19 & 29,56 & 31,37 & 34,78 & 25,81 & 37,35 & 31,83 \\
\hline
\end{tabular}




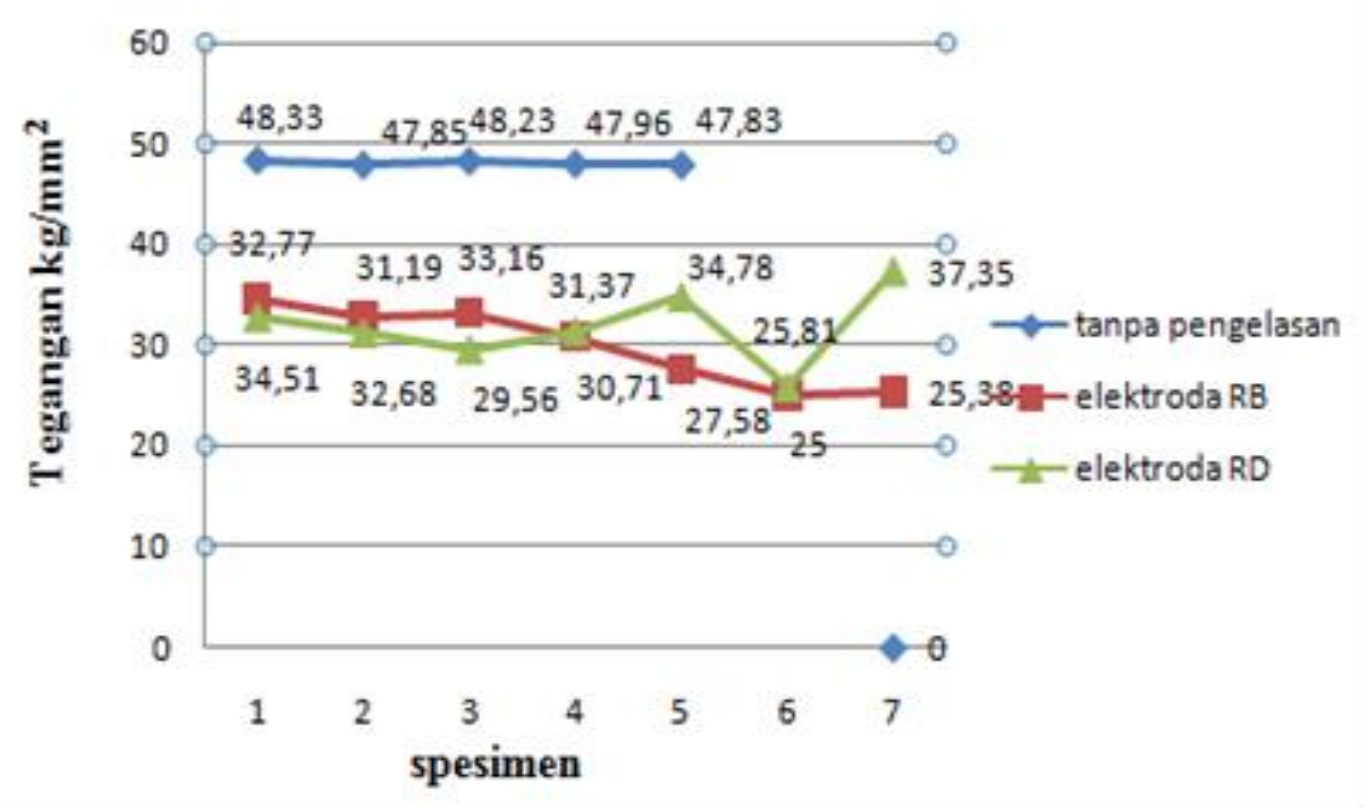

Figure 2 : Graph of Tensile Test Result

\section{DISCUSSION}

Based on the tensile strength test it was found that the tensile strength of the specimen without welding obtained the tensile strength of the specimen as follows: test 1 tensile strength obtained by $44,33 \mathrm{~kg} / \mathrm{mm}^{2}$, test 2 is $47,85 \mathrm{~kg} / \mathrm{mm}^{2}$, test 3 is $48,23 \mathrm{~kg} / \mathrm{mm}^{2}$, test 4 is $47,96 \mathrm{~kg} / \mathrm{mm}^{2}$, test 5 is $47,83 \mathrm{~kg} / \mathrm{mm}^{2}$. The above data obtained the average tensile strength of $48,16 \mathrm{~kg} / \mathrm{mm}^{2}$ with the tensile strength of the largest specimen ie $48.33 \mathrm{~kg} / \mathrm{mm}^{2}$ and the tensile strength of the lowest specimen $47.83 \mathrm{~kg} / \mathrm{mm}^{2}$. In welding of RB type electrodes, the tensile strength of the specimens is as follows: in test 1 is $34,51 \mathrm{~kg} / \mathrm{mm}^{2}$, test 2 is 32,68 $\mathrm{kg} / \mathrm{mm}^{2}$, test 3 is $33,17 \mathrm{~kg} / \mathrm{mm}^{2}$, test 4 is $30,71 \mathrm{~kg} / \mathrm{mm}^{2}$, test 5 is $27,58 \mathrm{~kg} / \mathrm{mm}^{2}$, test 6 is $25,01 \mathrm{~kg} / \mathrm{mm}^{2}$, test 7 is $25,38 \mathrm{~kg} / \mathrm{mm}^{2}$. From the above data obtained the average tensile strength of $29.86 \mathrm{~kg} / \mathrm{mm}^{2}$ with the tensile strength of the largest specimen ie $34.51 \mathrm{~kg} / \mathrm{mm}^{2}$ and the tensile strength of the lowest specimen 25.00 $\mathrm{kg} / \mathrm{mm}^{2}$. In welding of RD type electrodes, the tensile strength of the specimens is as follows: in test 1is $32,77 \mathrm{~kg} / \mathrm{mm}^{2}$, test 2 is $31,19 \mathrm{~kg} / \mathrm{mm}^{2}$, test 3 is $29,56 \mathrm{~kg} / \mathrm{mm}^{2}$. test 4 is $31,37 \mathrm{~kg} / \mathrm{mm}^{2}$, test 5 is 34,78 $\mathrm{kg} / \mathrm{mm}^{2}$, test 6 is $25,81 \mathrm{~kg} / \mathrm{mm}^{2}$, test 7 is $37,35 \mathrm{~kg} / \mathrm{mm}^{2}$. From the above data obtained the average tensile strength of $31.83 \mathrm{~kg} / \mathrm{mm}^{2}$ with the tensile strength of the largest specimen ie $34.51 \mathrm{~kg} / \mathrm{mm}^{2}$ and the tensile strength of the lowest specimen $25.81 \mathrm{~kg} / \mathrm{mm}^{2}$. From the results of the analysis can be obtained that the specimens are welded by electrode type RB has an average tensile strength $29.86 \mathrm{~kg} / \mathrm{mm}^{2}$ while the specimen welded using RD type electrodes has an average tensile strength of $31.83 \mathrm{~kg} / \mathrm{mm}^{2}$

\section{CONCLUSION}

Based on data analysis and discussion on this tensile strength test, it can be concluded that welding is also influenced by the type of electrode used so as to give effect to tensile strength of low carbon steel welding (St 37) by using electric welding. The resulting tensile strength of low carbon steel welding (St 37) using RB electrode has an average tensile strength of $29.86 \mathrm{~kg} / \mathrm{mm}^{2}$. Furthermore, at low carbon steel welding (St 37) using RD electrodes yields an average tensile strength of $31.83 \mathrm{~kg} / \mathrm{mm}^{2}$. Thus, the welding results using $\mathrm{RD}$ electrodes have a higher mean tensile strength than those using $\mathrm{RB}$ electrodes that are affected by the chemical structure dependent on the manufacture of the electrode. Tensile strength is one of the properties of materials that can be used to determine the characteristics of the material while subjected to loading. The strength of a material can be seen from the value of its tensile strength, the higher its tensile strength the material is stronger. 


\section{REFERENCE}

[1] Daryanto. Teknik Las. Bandung: ALFABETA. 2012

[2] Sofyan, B. T. Pengantar Material Teknik. Jakarta: Salemba Jakarta. 2010

[3] Suryana, D. and Sidabutar, D. Petunjuk Praktek Las. Jakarta: Mutiara. 1978.

[4] Wiryosumarto, H. and Okumura, T. Teknologi Pengelasan Logam. Jakarta: Pradya Paramita. 2008.

[5] Edih Supardi. Pengujian Logam. Bandung: Angkasa Bandung. 1991. 